\title{
Suicide attempt among substance users: Do aggression and polysubstance use have an interaction effect on suicide attempt
}

\author{
Madde kullanıcılarında intihar girişimi: Agresyon ve çoklu madde \\ kullanımının etkileşimi intihar girişiminde etkili midir?
}

Tugba Gorgulu1
${ }^{1}$ Assis. Prof.,Department of Social Work, Istinye University, Istanbul, Turkey; Department Of Psychiatry, University Of Rochester, NY-US.
https://orcid.org/0000-0002-5440-7354

\section{SUMMARY}

Objective: Suicide attempt is more common among substance users than general population. There are several risk factors effect suicide attempt among substance users. Polysubstance use and aggression are the most two important risk factors for suicide attempt. However, it is unclear how aggression and polysubstance use, and their interaction are associated with suicide attempts among substance users. Method: It was studied with 257 participants who completed the socio-demographic form (including substance use and suicide attempt history) and Hostility Scale to assess the aggression. Lifetime suicide attempt was assessed by the question as "Have you ever tried to kill yourself or have you ever attempt suicide?" Polysubstance use was assessed by the question "How many drug do you use? Results: To find the predictive variable of suicide attempts logistic regression analysis was conducted. The analysis indicate that the best predictors of suicide attempt was having friends with substance use behavior in childhood of adolescent period, having substance users in family members, polysubstance use and aggression; but there was no a significant interaction between polysubstance use and aggression on suicide attempt. Discussion: It is clear that aggression and polysubstance use are important risk factors for suicide attempts. For this reason, it is recommended that anger management based studies should be carry out to prevent suicidal behavior among substance users.

Key Words: Suicide attempt, polysubstance use, multiple drug use, aggression, substance use

\section{ÖZET}

Amaç: Madde kullanımı olan bireylerde intihar girişimi genel nüfusa göre daha yüksektir. Bu bireylerde intihar girişimine neden olan birçok risk faktörü vardır. Çoklu madde kullanımı ve agresyon bu risk faktörler arasında en önde gelenleridir. Ancak madde kullanımı olan bireylerde agresyon ve çoklu madde kullanımının, ayrıca bu iki faktörün etkileşiminin intihar girişimi üzerindeki etkisi açık değildir. Yöntem: Bu çalışmada sosyodemografik bilgi formu ile agresyonu ölçmek için kullanılan Düşmanlık Ölçeği'ni dolduran 257 madde kullanıcısıyla çalışı Imıştır. Yaşam boyu intihar girişimi “Hiç kendinizi öldürmeye çalıştınız $\mathrm{mı}$ ya da hiç intihar girişiminde bulundunuz mu? sorusuyla, çoklu madde kullanımı ise "Kaç adet madde kullanıyorsunuz?" sorusuyla ölçülmüştür. Bulgular: İntihar girişiminin yordayıcı değişkenlerini bulmak için lojistik regresyon analizi yapılmıştır. Analiz sonuçlarına göre, intihar girişiminin en önemli değişkenlerinin çocukluk ve adolesan döneminde madde kullanımı olan arkadaşların olması, ailede madde kullanım davranışı olması, çoklu madde kullanımı ve agresyon olduğu bulunmuştur. Ancak çoklu madde kullanımı ve agresyon etkileşiminin intihar girişimi üzerinde anlamlı bir etkisi olmadığı görülmüştür. Sonuç: Çoklu madde kullanımı ve agresyon intihar girişimi için önemli risk faktörleridir. Bu nedenle madde kullanıcılarıyla öfke kontrol çalışmalarının yapılması intihar girişimlerinin önlenmesi için önemli olduğu düşünülmektedir.

Anahtar Sözcükler: İntihar girişimi, çoklu madde kullanımı, agresyon, madde kullanımı

(Turkish J Clinical Psychiatry 2020;23:430-437)

DOI: $10.5505 / \mathrm{kpd} .2020 .56887$ 


\section{INTRODUCTION}

Every year an average of one million people die by suicide worldwide. Suicide has been increasing over the last three decades and it is the tenth leading cause of death $(1,2)$. It has been especially alarming among adolescents. Deaths by suicide among the individuals aged 15-29 are the second most common cause of death (3). There are many risk factors for completed suicide. Suicide attempt is a major risk factor for completed suicide. According to the statistics $20 \%$ of suicide attempters will make the second suicide attempt within 12 months after the first attempt. Furthermore the risk of a second attempt is about $50 \%$ on average. (4). Epidemiological studies on this issue have shown that suicide attempt, which is very complicated behavior, is explained by many risk factors. In addition to various psychiatric and social problems (5, 6 ), substance use is a major risk factor for suicide attempt (7).

Many drug users attempt suicide, and suicide attempt is more common in substance users than the general population, with $20 \%$ of women and $40 \%$ of men who use alcohol, are attempting suicide at least once in their life time (8). The risk of suicide attempts among cannabis users is four times higher than those who do not (9). Twenty-nine percent of the individuals who attempted suicide are explained by cocaine user and $40 \%$ of cocaine users have a life time suicide attempt(s) history (10). The most risky group is opiate users. Opiate users attempt suicide with violent method within 12 months after they began to use opiate (11). According to Pompili and his colleagues (2010), $40 \%$ of the patients treated for alcohol and substance use attempted suicide at some time in their lives (12). Studies also have focused on the relationship between use of polysubstance use and suicide attempts $(13,14)$ Studies on polysubstance use behavior indicate that polysubstance use is an important risk factor for suicide attempt. Accordingly, suicide risk increases as the number of substances increases (13). The study conducted by Kokkevi and colleagues (15) showed that suicide attempt risk doubled with every drug used, and the method of suicide attempt was more likely to be fatal.
Undoubtedly, suicidal behavior is an aggression behavior towards the self (16). Anger is a very important risk factor for suicide and suicide attempt behavior (17) Experts on this topic emphasize that substance use behavior also is a kind of aggressive behavior against the self (18). Researchers focus on the relationship between substance use, suicide attempt and aggression $(19,20)$. Gvion et al. (21) indicated that substance users did not have to intend to commit suicide, and that the individual may have given harm himself/herself due to aggression or impulsive behavior caused by substance use. But it is known that substance users use more violent methods in suicidal behavior. Undoubtedly, this situation results in using a more lethal method because of increases of anger (22).

Aforementioned to the literature information on suicide attempts, it seems that suicide attempts are high among substance users and polysubstance users (15). In addition, aggression is a major risk factor for suicide attempts. Also polysubstance users are prone to be more aggressive than those who use only one substance (22). However, those studies on this topic mostly investigate the effect of polysubstance use or aggression alone on suicide attempt. But still it is unclear the interaction effect of aggression and polysubstance use on suicide attempts. Therefore, the aim of this study was to investigate the effects of variables related to substance use, polysubstance use and aggression on suicide attempt history. I hypothesized that polysubstance use and aggression would be positively associated with suicide attempt behavior. Also the interaction between polysubstance use and aggression would have an effect suicide attempt history.

\section{METHOD}

\section{Sample}

This study was carried out with 257 male substance users in Ankara Probation Department (APD). The participants who were at least aged of 18 years and able to speak and read in Turkish were included to the study. The individuals who had difficulty in reading comprehension, cognitive impairment and currently diagnosed with psychiatric disorders which are highly related to suicide attempt were 
excluded. It was searched that the participants who directed to APD for substance use behavior should have substance use disorder criteria specified in the Diagnostic and Statistical Manual of Mental Disorders (DSM-5).

\section{Procedure}

Before beginning the study, participants were informed about the study. Participants who did not want to participate or were disturbed during the application could be withdrawn from the study. After this process, Informed Consent Form was given to the participants who approved to attend to the study. The study was approved by the Ministry of Justice and the ethical committee of Hacettepe University.

\section{Measures}

Sociodemographic Data Form: The form was prepared by the researcher, this form includes entries collecting psychosocial data related to substance use behavior, suicide attempt and risk factors of suicide attempt as well as some demographic questions about age, marital status and income.

Lifetime history of suicide attempt: It was assessed by self-report yes/no question. Participant were asked "Have you ever tried to kill yourself or have you ever attempt suicide?" This item was obtained from the National Comorbidity Survey (23). In this study, 67 participants $(26.1 \%)$ reported one or more previous lifetime suicide attempts.

Polysubstance Use: It is assessed by self-report yes/no question. Participant were asked "How many drug do you use?" In this sample $43.5 \%$ of the participants were using multiple drugs.

Aggression: Aggression was assessed by Hostility Scale which is a subscale of Suicide Probability Scale. It was developed by Cull and Gill (24). The Hostility Scale has 7 items like "When I get mad I throw things" or "I feel tend to be impulsive". The scale is answered on a 4-point Likert-type scale such as "never or rarely", "sometimes", "often" and "most of the time" or "all the time". The psychome- tric study of the SPS was conducted with 1100 adults. According to the study, the internal consistency coefficient was .58 for Hostility Scale (24). In the current sample of this study the internal consistency for the scale was good $(\dot{\sim}=.65)$.

\section{Statistical Analysis}

To test the study data for normal distribution, all total score of scales were converted to " $\mathrm{z}$ " scores, confirming normal distribution. To find predictive variables of suicide attempt, logistic regression analysis was carried out (25), and the HosmerLemeshow Goodness-of-fit-test (HL) were used to assess model fit (26).

Before applying logistic regression analysis, Pearson Product-Moment Correlation was calculated to determine multicollinearity between covariates. It was concluded that there was no problematic multicollinearity.

To test the primary hypotheses predictive variables (age of onset of drug use, duration of drug use, drug use friends in childhood and adolescent, substance use in family member, polysubstance use, aggression) were added as predictors in the first step. In the second step, the two-way interactions (aggression x polysubstance use) was included. All statistical analyses were performed using SPSS 20 (IBM).

\section{RESULTS}

\section{Socio-demographic and psychosocial results of participants}

The mean age of the participants was $30(\mathrm{SD}=$ 9.08) and the participants averaged 8 years of education $(\mathrm{SD}=1.13)$. The majority of participants were single $(58.8 \%)$. When considering the substance use the majority of participants (56.4\%) were using only one drug, and the others were using multiple drugs $(43.5 \%)$. Majority of them used cannabis $(91.8 \%)$, ecstasy $(38.9 \%)$, bonsai $(24.1 \%)$, crack $(20.2 \%)$, heroin $(18.3 \%)$, and cocaine $(18.3 \%)$. 
Table 1. Bivariate Correlations and Descriptive Statistics.

\begin{tabular}{|c|c|c|c|c|c|c|}
\hline & 1 & 2 & 3 & 4 & 5 & 6 \\
\hline 1. Age Onset of Drug Use & ---- & & & & & \\
\hline 2. Duration of Drug Use & $-.22^{* *}$ & ---- & & & & \\
\hline 3. Drug Users Friends & $.43 * *$ & -.09 & ---- & & & \\
\hline 4. Drug Users in Family & $.16^{*}$ & -.21 & .11 & ---- & & \\
\hline 5. Number of Drug & $-.28 * *$ & $-.23 * *$ & $-.22 * *$ & $.16^{*}$ & ---- & \\
\hline 6. Hostility & $-.26^{*}$ & -.11 & -.10 & -.10 & $.14^{*}$ & ---- \\
\hline M & ---- & --- & --- & ---- & ---- & 13.96 \\
\hline SD & --- & --- & ---- & ---- & ---- & 4.18 \\
\hline Min. & ---- & ---- & ---- & ---- & ---- & 7.00 \\
\hline Max. & ---- & ---- & ---- & ---- & ---- & 32.00 \\
\hline
\end{tabular}

Note. $\mathrm{n}=257,{ }^{*} \mathrm{p}<.05,{ }^{* *} \mathrm{p} .01,{ }^{* * *} \mathrm{p}<0.001$; Age of onset of drug use: 5 categories; Before the aged of 18, aged of 18-23, aged of 24-29, aged of 30-35, 36 and over; Duration of drug use: 5 categories; 0-6 months, 7-12 months, 13-24 months, 2536 months, 37 months and over; Having drug user friends in childhood and adolescent period $=($ Coded: 0 Yes- 1 No); Substance user in family members $=($ Coded: 0 Yes- 1 No); Number of Drug: One drug use $(n=144)$, Polysubstance use $(\mathrm{n}=111)$

$54.1 \%$ of the participants stated that they began to use substance before the aged of 18 , and $70 \%$ of them stated that they used substance more than 3 years. $71.6 \%$ of the participants had substance user friends in their childhood or adolescent period. $83 \%$ of participants had friends who currently use several substance. $37.4 \%$ of the participants had at least one family member who use drug.

$35.4 \%$ of the participants had suicidal ideation and $26.1 \%$ had lifetime suicide attempt. Of the participants who attempted suicide, $40 \%$ attempted by overdosing medicine, $38.5 \%$ self-cutting, $15.4 \%$ hanging, $4.6 \%$ jumping from a high and $1.5 \%$ firearm.

\section{Bivariate Correlations of Variables}

To find out if there was multicollinearity between variables, Pearson Product-Moment Correlation was calculated. According to the results there was no high correlation between the variables. It was found that there was only significant correlation between aggression and onset age of drug use ( $\mathrm{r}_{0}$

Table 2.Logistic Regression Analysis on the Main Effect of and Interactions Between Aggression and Polysubstance Use

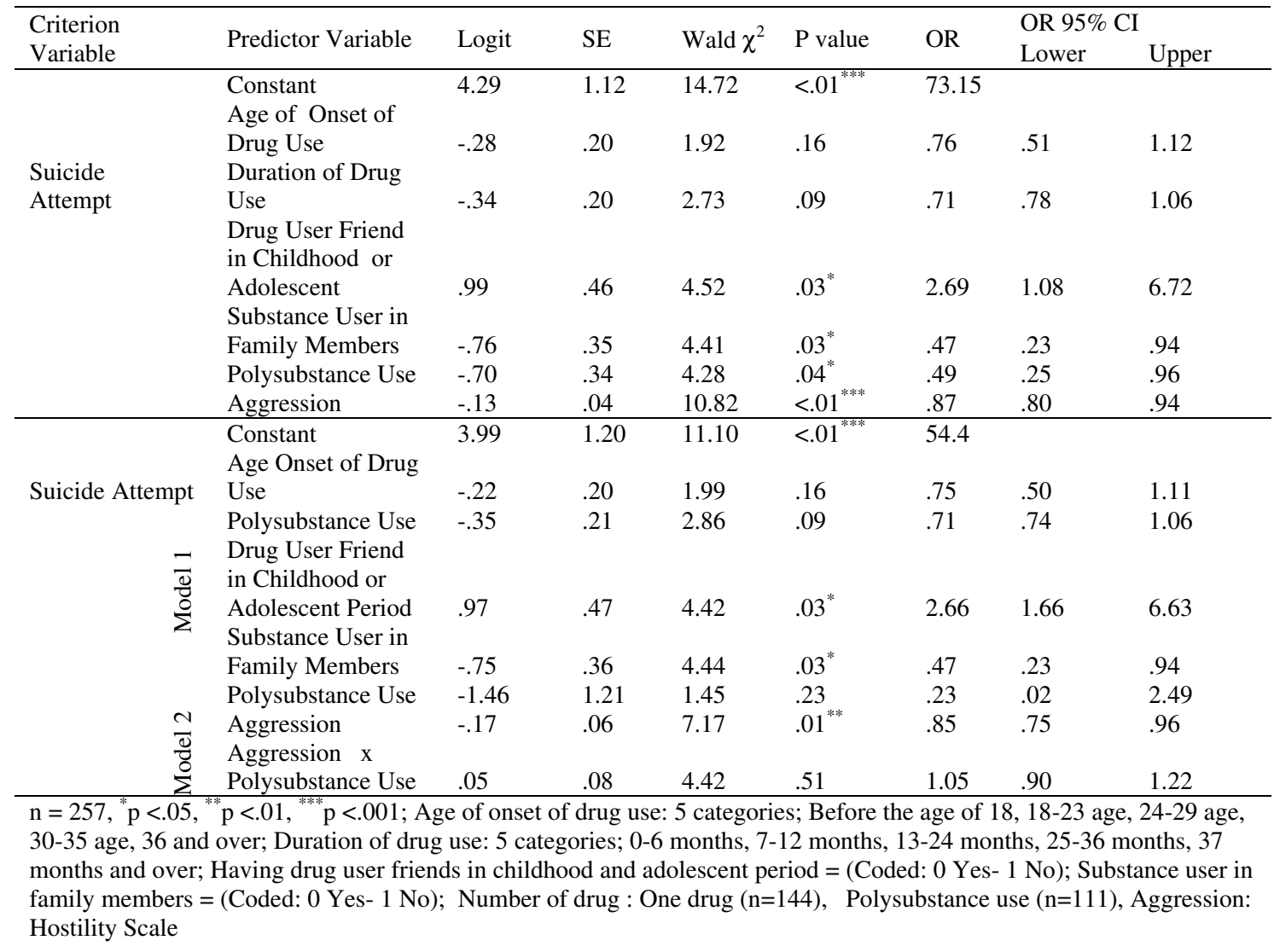


$=-.22, p<.001)$. This result indicates that when onset age of drug use decrease, aggression is increasing. When considering the other variables, there was a significant correlation between the onset age of drug use and duration of drug use $\left(\mathrm{r}_{\mathrm{O}}\right.$ $=-.22, \mathrm{p}<.001)$, having substance users family members $\left(\mathrm{r}_{\mathrm{O}}=-.16, \mathrm{p}=04\right)$ and polysubstance use $\left(r_{0}=-.28, p=.01\right)$. Finally there was significant correlation between duration drug use and polysubstance use $\left(\mathrm{r}_{\mathrm{O}}=-.23, \mathrm{p}=.01\right)$. The result indicates that as duration drug use increases, the number of using drug increases.

\section{Primary Analysis}

Logistic regression analysis was conducted to find out the best predictive variables of suicide attempt. First, the main affects were tested. It is seen that the results were significant $\left(\mathrm{x}^{2}[6, \mathrm{~N}=257]=27.21\right.$, $\mathrm{p}<.001$; Nagelkerke $\left.\mathrm{R}^{2}=.16\right)$, and the HL test showed that the data is fits the model $\left(\mathrm{x}^{2}=9.95, \mathrm{p}\right.$ $>.05$ ). According the results, there was a significant main effects of having drug user friends in childhood and adolescent period $(\mathrm{OR}=2.70, \mathrm{p}=.03)$, having substance users in family members $(\mathrm{OR}=$ $.47, \mathrm{p}=.03)$, polysubstance use $(\mathrm{OR}=.50, \mathrm{p}=.04)$ and aggression $(\mathrm{OR}=.87, \mathrm{p}<.01)$ on suicide attempt.

To find out the moderation effect of aggression and polysubstance use the two way interactions were added to logistic regression model. According the analysis, the model was significant for suicide attempt history $\left(\mathrm{x}^{2}[6, \mathrm{~N}=257]=27.64, \mathrm{p}<.001\right.$; Nagelkerke $\left.\mathrm{R}^{2}=.17\right)$ and the HL test showed that the data is fit the model $\left(x^{2}=6.46, p>.05\right)$. However, as seen in Table 2, there was no a significant interaction effect of aggression and polysubstance use on suicide attempt history $(\mathrm{OR}=.42, \mathrm{p}$ $=.08$ ). This result indicate that aggression and polysubstance use together were not mediate suicide attempt history.

\section{DISCUSSION}

In this study, the best predictive variables of suicide attempt history and the effect of polysubstance use and aggression on suicide attempt history were investigated. According to the results, I found that there was no interaction effect of aggression and polysubstance use on suicide attempt history. On the other hand it was found that in this study, aggression and polysubstance use behaviors are separately important variables for suicide attempt(s). This result may be because the anger is a more dominant variable for suicide attempt. Because aggression was an important variable both in the main analysis and interaction analysis. Studies in the suicide attempt literature focus on the relationship between anger, hostility and suicide. Those studies are also focus on the relationship between suicide and impulsive behaviors $(27,28)$. These results may indicate that individuals can impulsively direct anger to their selves and it may result with suicidal behavior. Consistent with the previous studies I found that aggression was an important risk factor for suicide attempt among substance users. Therefore, I thought that anger management therapies should be done with substance users, and these studies should be based on the cognitive and behavioral approaches. Therefore substance users could gain ability how to express their anger to their self and to others properly.

In this study, I found that polysubstance use is an important risk factor for suicide attempt. The result is consistent with previous studies on suicide attempt history among polysubstance users. Studies have suggested that more than one substance use increases the risk of suicide attempt(s) (13-15) and with every substance, suicide attempt risk increase double fold (15). Most polysubstance users also use high-purity substances. This problems may increase negative biopsychosocial conditions. Therefore I recommend that in addition to psychosocial prevention studies, also medical prevention studies should be conducted with polysubstance users.

I found that substance user friends during childhood or adolescence period is a risk factor for suicide attempt history. However it has not been examined whether this result is due to the longterm substance use behavior. On the other hand studies have drawn attention to the relationship between long term substance use and suicidal behavior (29). Nevertheless, having substance use friends during childhood or adolescent period may means that the participants are familiar with sub- 
stances and they are living in a negative social environment. This situation may an obstacle for learning coping and positive problem solving skills for the individuals who have substance user friends in their childhood. Therefore, it is important to conduct psychosocial studies to prevent substance use among school age adolescents and students. At this point, psychosocial studies should be conducted with the students who are at a risk of substance use.

In this study, it was found that substance use behavior in family members is a risk factor for suicide attempt. This result indicates that substance use behavior in family members adversely affects participant's well-being. Undoubtedly, substance use behavior in family members adversely affects the functionality of the family system (30). This negative situation may have increased the risk of suicide attempt(s). On the basis of this result, the other way to prevent suicide attempts is to study with the family system. Therefore medical and psychosocial studies should be conducted with substance user family members to prevent suicide attempt.

According to the results of this study, it was found that the majority of substance users began to use substances before aged of 18 and that majority of them have drug user friends in their childhood and adolescence period. Participants also have substance use behavior in their family members. These results consistent with the previous studies in the literature. Studies have shown that majority substance users have substance use behavior in family members and friends $(31,32)$. Undoubtedly, in this study it was not examined the effect of family and friend effect on substance use behavior of the participants. However, I thought that being substance use behavior among family members and friends may result individuals to learn and internalize the substance use behavior.

In this study it was found that there was a relationship between early onset drug use and current polysubstance use. The result indicates that individuals who begin substance use at early age are prone to later polysubstance use. Studies have shown that early onset of drug use is an important indicator of polysubstance use $(34,35)$. Strunin and colleagues (36) found that there was a robust relationship between early onset substance use and later polysubstance use among both women and men. They also claimed that, especially the polysubstance users who begun substance use before aged of 15 were more prone to current polysubstance use. Considering all those literature information I suggest that psychoeducation studies should be conduct in elementary school. Also those studies should be consider as a macro policy in Ministry of National Education.

There are some limitation of this study. The most important limitation of this study is that it is studied only with male individuals. Therefore, the effect of gender factor on suicide attempt could not be determined. Considering that substance use behavior is more intense in men than women and suicide attempts are higher in women than men (33). For this reason the difference between substance use behavior in men and women may make a significant difference for suicide attempt. Therefore, it is recommended that further studies should be conducted with female participants to reveal the gender differences for suicide attempt behavior. Secondly, this study is a cross-sectional study. Each participants were interviewed in short time and the related scales were filled in one session. Therefore, it is suggested that prospective studies should be performed to measure the impact of aggression and polysubstance use on suicide attempt.

\section{CONCLUSION}

In conclusion, I examined the relationship between polysubstance use behavior and aggression, and the interaction between polysubstance use behavior and aggression on suicide attempt history. I found that polysubstance use and aggression are two major risk factors for suicide attempt history but there was no interaction effect between polysubstance use behavior and aggression on suicide attempt history. In addition to those two risk factors, I found that presence of substance use friends during their childhood and adolescent period is an important predictive risk factor for suicide attempt history. Also family system may be a protective factor for prevention for suicide. I found that substance use behavior among family members is a predictive for suicide attempt. Finally, there was a 
Suicide attempt among substance users: do aggression and

significant relationship between early substance use behavior and current polysubstance use behavior. Substance users who begun to use drug before age of 18 are prone to polysubstance use behavior.
Correspondence address: Assis. Prof. Tugba Gorgulu, Department of Social Work, Istinye University, Istanbul, Turkey; Department of Psychiatry, University of Rochester, NYUS. tgorgulu@istinye.edu.tr

\section{REFERENCES}

1. WHO. World Health Report 2001: Mental health: new understanding, new report 2001: mental health: new understanding, new hope 2001; Geneva.

2. CDC. CDC Vital Signs. Centers for Disease Control and Prevention. 2018 Retrieved May 05 2019, Available from https://www.cdc.gov/vitalsigns/pdf/vs-0618-suicide-H.pdf

3. WHO. Latest data on suicide. 2018 Retrieved April 182019 , Available from https://www.who.int/mental_health/suicide-prevention/en/

4. Schmidtke A, Bille-Brahe U, DeLeo D, Kerkhof A, Bjerke T, Crepef, P., . . . Michel K. Attempted suicide in Europe: rates, trend. S and sociodemographic characteristics of suicide attempters during the period 1989-1992. Results of the WHO/EURO Multicentre Study on Parasuicide. Acta Psychiatr Scand 1996; 93(5): 327-338.

5. DeVylder JE, Lukens EP, Link BG, Lieberman JA. Suicida ideation and suicide attempts among adults with psychotic experiences: data from the collaborative psychiatric epidemiology surveys. JAMA psychiatry 2015; 72: 219-225.

6. Hoertel N, Franco S, Wall M, Oquendo M, Kerridge B, Limosin F, Blanco C. Mental disorders and risk of suicide attempt: a national prospective study. Mol Psychiatry 2015; 20 : 718-726.

7. Darvishi N, Farhadi M, Haghtalab T, Poorolajal J. Alcoholrelated risk of suicidal ideation, suicide attempt, and completed suicide: a meta-analysis. PloS one 2015; 10(5): e0126870.

8. Rygnestad T, Stiles T, Bjerke T, Jorgensen P. Fatal and nonfatal repetition of parasuicide. Suicidal Behaviour in EuropeRecent Research Findings. John Liebey, London; 1992; 183-190.

9. Harris EC, Barraclough B. Suicide as an outcome for mental disorders. A meta-analysis. Br J Psychiatry 1997;170: 205-228.

10. Roy, A. Characteristics of cocaine dependent patients who attempt suicide. Arch Suicide Res 2009; 13: 46-51.

11. Miotto K, McCann MJ, Rawson RA, Frosch D, Ling W. Overdose, suicide attempts and death among a cohort of naltrexone-treated opioid addicts. Drug and Alcohol Dependence 1997; 45: 131-134

12. Pompili M, Serafini G, Innamorati M, Dominici G, Ferracuti S, Kotzalidis GD, ... Tatarelli R. Suicidal behavior and alcohol abuse. Int J Environ Res public Health 2010; 7: 1392-1431.

13. O'Boyle M, Brandon EA. Suicide attempts, substance abuse, and personality. J Subst Abuse Treat 1998; 15: 353-356.

14. Reyes JC, Robles RR, Colón HM, Negrón JL, Matos TD Calderón JM. Polydrug use and attempted suicide among Hispanic adolescents in Puerto Rico. Arch. Suicide Res. 2011; 15: 151-159.

15. Kokkevi A, Richardson C, Olszewski D, Matias J,
Monshouwer K, Bjarnason T. Multiple substance use and selfreported suicide attempts by adolescents in 16 European countries. Eur Child Adolesc Psychiatry 2012; 21: 443-450.

16. Berkowitz, N. Aggression: Its causes, consequences, and control .1993; New York: McGraw-Hill.

17. Şahin, N. H., Onur, A., \& Basım, H. N. İntihar olasilığının öfke, dürtüsellik ve problem çözme becerilerindeki yetersizlik ile yordanması. Türk Psikoloji Dergisi 2008; 23:79-88.

18. Miczek, K. A., DeBold, J. F., Haney, M., Tidey, J., Vivian, J., \& Weerts, E. M. Alcohol, drugs of abuse, aggression, and violence. 1994; Understanding and preventing violence, 3: Social Influences.

19. Canetto SS. Gender roles, suicide attempts, and substance abuse. J Psychol 1991; 125: 605-620.

20. Koller G, Preuss U, Bottlender M, Wenzel K, Soyka M. Impulsivity and aggression as predictors of suicide attempts in alcoholics. Eur Arch Psychiatry Clin Neurosci 2002;252:155-160.

21. Gvion Y, Apter A. Aggression, impulsivity, and suicide behavior: a review of the literature. Arch Suicide Res 2011;15: 93-112.

22. Held T, Hawellek B, Dickopf-Kaschenbach K, SchneiderAxmann T, Schmidtke A, Möller H. Violent and non-violent methods of parasuicide: what determines the choice? Fortschr Neurol Psychiatr 1998;66:505-511

23. Kessler RC, Borges G, Walters EE. Prevalence of and risk factors for lifetime suicide attempts in the National Comorbidity Survey. Arch Gen Psychiatry 1999; 56: 617-626.

24. Cull JG, Gill WS. Suicide probability scala (SPS) manual. 1998; Los Angeles: Western Psychological Services.

25. Tabachnick BG, LS Fidell, JB. Ullman, Using multivariate statistics. Vol. 5. 2007: Pearson Boston, MA

26. Hosmer D, Lemeshow S. Applied logistic regression. Vol. 398. 2013: John Wiley \& Sons

27. Swogger MT, Van Orden KA, Conner KR. The relationship of outwardly directed aggression to suicidal ideation and suicide attempts across two high-risk samples. Psychol Violence 2014; 4: 184-195.

28. Dougherty DM, Mathias CW, Marsh DM, Papageorgiou TD, Swann AC, Moeller FG. Laboratory measured behavioral impulsivity relates to suicide attempt history. Suicide Life Threat Behav 2004 ;34:374-85.

29. Miguel-Hidalgo JJ, Overholser JC, Meltzer HY, Stockmeier CA, Rajkowska G. Reduced glial and neuronal packing density in the orbitofrontal cortex in alcohol dependence and its relationship with suicide and duration of alcohol dependence. Alcohol Clin Exp Res 2006; 30: 1845-1855. 
30. VanderBroek L, Acker J, Palmer AA, de Wit H, MacKillop $\mathrm{J}$. Interrelationships among parental family history of substance misuse, delay discounting, and personal substance use. Psychopharmacology 2016; 233: 39-48.

31. Görgülü, T. Substance use risk factors and the results of substance use behaviors: A qualitative study on the experiences of substance users. Addicta: The Turkish Journal on Addictions; 6: $511-538$.

32. Poelen EA, Engels RC, Van Der Vorst H, Scholte RH,Vermulst AA. Best friends and alcohol consumption in adolescence: A within-family analysis. Drug Alcohol Depend 2007; 88:163-173.

33. Pelissier B, Jones N. A review of gender differences among substance abusers. Crime Delinq 2005; 51: 343-372.

34. Chuan-Yu C, Storr CL, Anthony JC. Early-onset drug use and risk for drug dependence problems. Addict Behav 2009; 3493: 319-322.

35. Dawson DA, Goldstein RB, Patricia CS, June Ruan W, Grant BF. Age at first drink and the first incidence of adult-onset DSM-IV alcohol use disorders. Alcohol Clin Exp Res 2008; 32: 2149-2160.

36. Strunin L, Díaz-Martínez A, Díaz-Martínez L., Heeren T, Chen C, Winter, M., ... Solís-Torres C. Age of onset, current use of alcohol, tobacco or marijuana and current polysubstance use among male and female Mexican students. Alcohol and Alcoholism 2017; 52: 564-571. 